Endocrinol. Japon. 1989, 36 (5), 635-639

\title{
Peroxidase Activities in Autonomously Functioning Nodules and Adjacent Non-Tumorous Portions of Thyroids
}

\author{
Hirokatsu YOSHIMURA, Osamu OZAKI**, KunihiKo ITO** AND \\ ToICHIRo HOSOYA*1) \\ *Faculty of Pharmaceutical Sciences, Chiba University, \\ Chiba 260 and **Ito Hospital, Tokyo 150 Japan
}

\begin{abstract}
Peroxidase activities of autonomously functioning thyroid tumors (T) and surrounding non-tumorous tissue $(\mathrm{N})$ in 5 patients were determined by employing guaiacol or iodide as the second substrates. The mean values for specific activities of $T$ were 30 times (in iodide oxidation assay) or 4 times (in guaiacol oxidation assay) as high as those in $\mathrm{N}$, being significantly higher than those of non-functioning tumors. The thyroglobulin-iodination activity of thyroid peroxidase in $\mathrm{T}$ was also found to correlate well to the iodide oxidation activity. These results suggest that the enhanced peroxidase activity in the nodules plays an essential role in the function of autonomously functioning thyroid nodules.
\end{abstract}

Autonomously functioning thyroid nodules (AFTN) are thyroid nodular lesions which are characterized by TSH-independent growth, functions and iodine uptake (Miller \& Hamburger, 1965; Hamburger, 1980, 1987). The incidence of AFTN is about $1 \%$ in the U.S. A. (Hamburger, 1987) and even lower in Japan (Ishida et al., 1983; Ito, 1984). Although a higher incidence was reported in Europe (Goretzki et al., 1985) and Brazil (Ferrazz et al., 1972), the pathogenesis of the disease remains unclear, and biochemical and immunological studies were also not fully performed. In terms of the activity of peroxidase which plays an important role in the synthesis of thyroid hormones, only a very limited

Received February 3, 1989

1) To whom correspondance should be addressed. number of reports have been published concerning the "hot" nodules or toxic adenoma (Nagasaka et al., 1975; Valenta. 1976; Fragu \& Nataf, 1977; Nakashima \& Taurog, 1978). In additon, their results did not necessarily agree with each other, probably due to the difference in assay procedures and control values.

Recently, we reported an improved peroxidase assay method which facilitates the assay for a minute amount of human thyroid tissues (Hosoya et al., 1985). Taking advantage of this assay method, we could compare the peroxidase activity of the lesion with that of the adjacent nontumorous portion in each thyroid with a non-functioning thyroid tumor (Yoshimura et al., 1988). In the present study, this method was applied to thyroids with AFTN. 
Table 1. Nodular size and laboratory data for 5 patients with autonomously functioning thyroid nodules

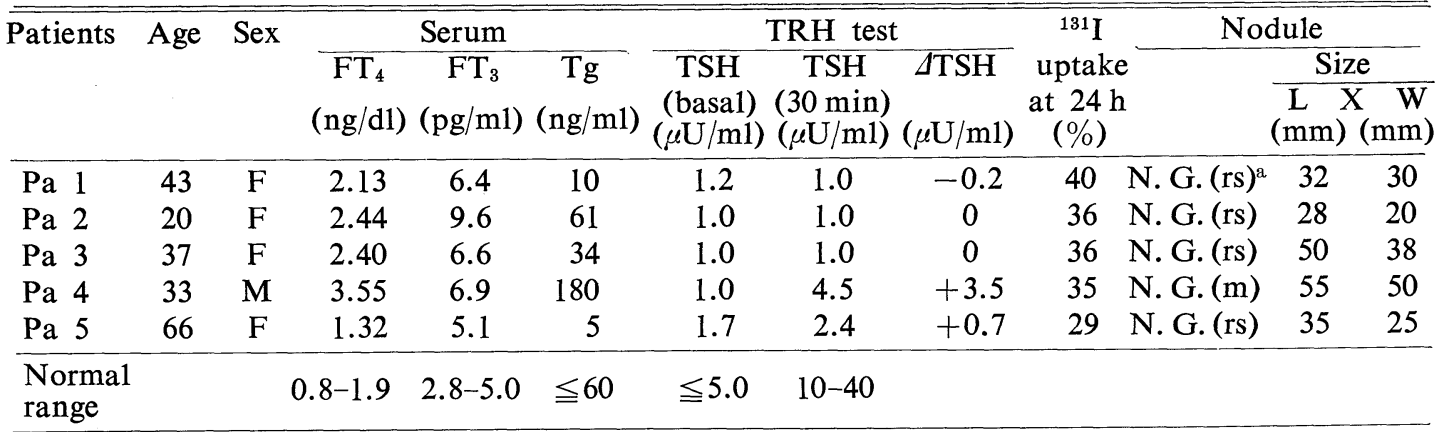

a. N. G. Stands for nodule goiter; rs : right side; $\mathrm{m}$ : middle.

\section{Materials and Methods}

\section{Patients}

Five patients with AFTN (Pa 1-Pa 5) were studied. A solitary nodularity was established on the basis of scintiscans. Thyroid function was evaluated on the basis of serum $\mathrm{FT}_{3}$ and $\mathrm{FT}_{4}$, and a TRH test (Table 1). The patients had been followed for 1-3 months before the study without antithyroid therapy. Thyroid tissues removed at surgery were separated into nodular portions and adjacent normal portions. A part of these tissues was used for histological examination and the remaining tissues were stored at $-80^{\circ} \mathrm{C}$ until use.

\section{Determination of TSH, FT $T_{3}, F_{4}$ and TRH tests}

Before the study, all patients had been off medication for at least one week. Serum TSH was determined before and $30 \mathrm{~min}$ after intravenous administration of $500 \mu \mathrm{g}$ TRH (Tanabe Seiyaku Co., Osaka). Serum $\mathrm{TSH}, \mathrm{FT}_{4}$ and $\mathrm{FT}_{3}$ were determined by radioimmunoassay using Amerlex TSH, $\mathrm{FT}_{4}$ and $\mathrm{FT}_{3}$ kits, respectively.

\section{Assay for peroxidase activity}

Homogenization and farctionation of thyroid tissues and solubulization of microsomal enzymes were carried out and the peroxidase activity was determined by the method described previously (Hosoya et al., 1985). The reaction was followed at $470 \mathrm{~nm}$ (guaiacol assay) or $350 \mathrm{~nm}$ (iodide assay) and the amount of enzyme which gave a change of 1.0 absorbance unit per second was taken as $1 g u$ or $1 i u$ in the "mini" assay and $1 \mathrm{GU}$ or $1 \mathrm{IU}$ in the "ordinary assay", respectively (Hosoya et al., 1985; Yoshimura et al., 1988; Takamatsu et al., 1988).

\section{Measurement of the rate of iodination of thyroglobulin catalyzed by thyroid per- oxidase}

The rate of iodination of thyroglobulin was measured as described previously (Yoshimura et al., 1988). The reaction mixture contained, in a total volume of $0.25 \mathrm{ml}, 0.05 \%$ human Graves' thyroglobulin $(\mathrm{I} / \mathrm{Tg}=0.26 \%), 0.1 \mathrm{mM} \mathrm{KI}, 60 \mu \mathrm{Ci}$ $\mathrm{Na}^{125} \mathrm{I}, 6.0 \mathrm{mM}$ glucose, $0.125 \mu \mathrm{g}$ glucose oxidase and the enzyme source ( $40 \mu \mathrm{g}$ protein). The enzyme source was prepared by solubilizing the thyroidal particulate fraction as described (Hosoya et al., 1985) and the initial rate of incorporation of iodine into thyroglobulin was determined. The unit of iodination activity was expressed as iodine incorporation into proteins in $\mathrm{n}$ moles/s/ $\mu \mathrm{g}$ protein.

\section{Determination of protein}

Protein was determined by the method of Lowry et al. (1957) with some modifications (Hosoya et al., 1985).

\section{Statistics}

Statistical analysis of the results was performed with Student's $t$-test. 


\section{Results}

The nodular lesion $(\mathrm{T})$ and adjacent non-tumorous portion $(\mathrm{N})$ of each thyroid were subjected for determination of per- oxidase activity. One specimen of each of 4 thyroids and two specimens of 1 thyroid were examined for the activity. The results are shown in Table 2, where $T / N$ denotes the ratio of the specific activity in $T$ to that in $N$. In both iodide assay and

Table 2. Peroxidase activities in nodular portion $(\mathrm{T})$ and adjacent non-tumorous portion (N) of AFTN. Peroxidase activities were determined by the "mini" assay method as described (Hosoya et al., 1985).

\begin{tabular}{|c|c|c|c|c|c|c|}
\hline \multirow[t]{3}{*}{ Patient } & \multicolumn{3}{|c|}{ Iodide assay } & \multicolumn{3}{|c|}{ Guiacol assay } \\
\hline & \multicolumn{2}{|c|}{$\begin{array}{l}\text { Specific activity } \\
(\mathrm{m} i u / \mathrm{mg} \text { protein) }\end{array}$} & \multirow[t]{2}{*}{$\mathrm{T} / \mathrm{N}$} & \multicolumn{2}{|c|}{$\begin{array}{l}\text { Specific activity } \\
(\mathrm{m} g u / \mathrm{mg} \text { protein) }\end{array}$} & \multirow[t]{2}{*}{$\mathrm{T} / \mathrm{N}$} \\
\hline & $\mathrm{N}$ & $\mathrm{T}$ & & $\mathrm{N}$ & $\mathrm{T}$ & \\
\hline \multirow{2}{*}{$\mathrm{Pa} 1\{$} & 14.5 & 164.0 & 11.5 & \multirow[t]{2}{*}{37.9} & 201 & 5.1 \\
\hline & & 69.2 & 4.8 & & 130 & 3.3 \\
\hline $\mathrm{Pa} 2$ & 24.2 & 397.0 & 16.4 & 34.4 & 225.0 & 6.5 \\
\hline $\mathrm{Pa} 3$ & 20.8 & 105.0 & 5.0 & 30.8 & 47.9 & 1.6 \\
\hline $\mathrm{Pa} 4$ & 37.3 & 69.2 & 2.4 & 25.9 & 47.7 & 1.8 \\
\hline $\mathrm{Pa} 5$ & 1.98 & 278.0 & 140.0 & 11.4 & 74.2 & 6.5 \\
\hline \multirow[t]{2}{*}{$\operatorname{Mean} \pm \mathrm{SE}$} & $19.8 \pm 5.8$ & $183.7 \pm 52.6$ & $30.0 \pm 22.1$ & $28.4 \pm 4.8$ & $121.0 \pm 31.7$ & $4.1 \pm 0.9$ \\
\hline & \multicolumn{2}{|c|}{$\mathrm{p}<0.05$} & & \multicolumn{2}{|c|}{$\mathrm{p}<0.05$} & \\
\hline \multicolumn{7}{|c|}{$\begin{array}{l}\text { Adenoma and } \\
\text { adenomatous } \\
\text { goiter }^{\mathrm{a}}\end{array}$} \\
\hline Mean & 35.1 & 105.3 & 6.4 & 49.8 & 107.9 & 2.6 \\
\hline
\end{tabular}

a. Taken from Yoshimura et al. (1988).

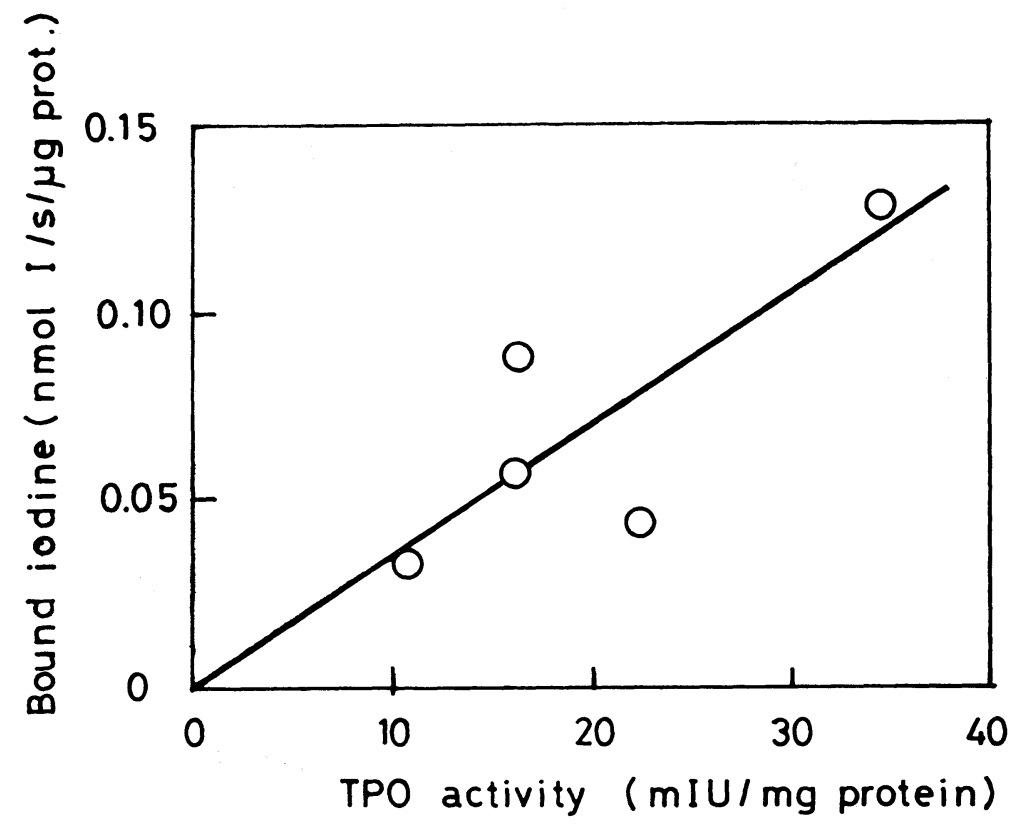

Fig. 1. Relationship between thyroglobulin iodination activity and iodide oxidation activity of TPO of AFTN. The microsome-mitochondrial fraction from AFTN was solubilized with $0.7 \%$ cholate at $0^{\circ} \mathrm{C}$ for $60 \mathrm{~min}$, followed by centrifugation at $105,000 \times g$ for 60 min. The supernatant obtained was used for determination of thyroglobulin oxidation activity and peroxidase activity ("ordinary assay") as described in Materials and Methods. 
guaiacol assay, peroxidase activities were higher in $\mathrm{T}$ than those in $\mathrm{N}$, thus giving mean $\mathrm{T} / \mathrm{N}$ ratios of 30.0 and 4.1 , respectively. The mean values in $\mathrm{T}$ of AFTN are $74 \%$ in iodide assay and $10 \%$ in guaiacol aaay-higher than those of nonfunctioning tumors determined previously in this laboratory. It is noteworthy that the mean values in $\mathrm{N}$ of AFTN are $44 \%$ (in iodide assay) and $43 \%$ (in guaiacol assay)-lower than those in $\mathrm{N}$ of nonfunctioning tumors. It was also found that the $\mathrm{T} / \mathrm{N}$ value for the guaiacol assay correlates well to that for the iodide assay $(\mathrm{r}=0.96)$, if the data for $\mathrm{Pa} 5$ whose $\mathrm{N}$ value in iodide assay was extremely low are excluded.

Fig. 1 shows the relationship between the thyroglobulin iodination activity and the iodide oxidation activity of TPO in these nodular tissues, indicating high correlation between them $(r=0.77)$.

\section{Discussion}

The incidence of functioning nodules in all thyroids with adenoma and adenomatous goiter is reported to be very low in Japan, i. e. $3.6 \%$ (Ishida et al., 1978) or $0.6 \%$ (Ito, 1984), as compared with $17.2-28.3 \%$ in Europe (Goretzki et al., 1985). The cause of such a difference in the frequency is still unclear. Some investigators (Torizuka, 1978 ; Ozaki et al., 1988) suspected that the difference in the amount of iodine intake may play an important role since Japanese take about 10 times as much iodine as European do (Torizuka, 1978 ; Soriba et al., 1985), and a similar difference between the frequency in patients in iodine-deficient areas and those in iodine-sufficient area in Sicily island has already been reported to (Belfiore et al., 1983). Even though it is the case, it remains to be elucidated how iodine deficiency causes the functioning nodules.
An any rate, the extremely low prevalence of AFTN makes it difficult to closely study the disease biochemically and immunochemically. In fact, little information is available on the peroxidase activity of AFTN in Japan. We report here the peroxidase activity in lesions in 5 patients with AFTN measured by both iodide oxidation and guaiacol oxidation assays as well as iodination activity. In addition, we were able to obtain, for the first time, the peroxidase of the adjacent normal portion in each thyroid tissue, thus providing the $\mathrm{T} / \mathrm{N}$ ratios of activities in each thyroid tissue.

The present studies demonstrated that the protein-based specific activities in $T$ of AFTN were considerably greater than those in $\mathrm{L}$ of non-functioning tumors both in iodide assay and guaiacol assay (Table 2). Furthermore, it is noteworthy that the activities in $\mathrm{N}$ were lower in thyroid of AFTN than in thyroid with non-functioning tumors. This is compatible with the supposition that the function of surrounding tissue of AFTN is suppressed by virtue of thyroid hormones produced autonomously in the lesion.

The present experiments were performed with thyroid tissues from 5 patients. Thus, experiments with more thyroids are needed to obtain conclusive results concerning AFTN. Moreover, it should be noticed that the peroxidase activities in two specimens of $\mathrm{Pa} 1$ were considerably different from each other (Table 2), suggesting that the activity in the lesion may not be uniform. Scintigrams often showed uneven patches of cold areas in the hot nodules. Therefore, it is necessary to examine the relationship between morphological observations and biochemical data for the tissue in the future.

It was confirmed that thyroglobuliniodination activity of AFTN correlates well with the iodide oxidation activity, suggesting that enhaced iodination activity of TPO is 
more or less responsible for the increased function of AFTN.

\section{Acknowledgements}

We thank Mr. Takeshi Ohmori for technical assistance. This work was supported in part by a Grant-in-Aid of Scientific Research from the Ministry of Education, Science and Culture, Japan.

\section{References}

Belfiore, A., S. F. Runello, L. Tomaselli and R. Vigners (1983). Solitary autonomously functioning thyroid nodules and iodine deficiency. J. Clin. Endocrinol. Metab. 56, 283287.

DeGroot, L. J. and H. Niepomniszcze (1977). Biosynthesis of thyroid hormone: basic and clinical aspects. Metabolism 26, 665-718.

Ferraz, A., G. A. Medeiras-Neto, A. C. Toledo and J. Fieffer (1972). Autonomous thyroid noudles I. A. clinical classification and the use of a diagnostic index. J. Nucl. Med. 13, 733-737.

Fragu, P. and B. M. Nataf (1977). Human thyroid peroxidase activity in benign and malign thyroid disorders. J. Clin. Endocrinol. Metab. 45, 1089-1096.

Goretzki, P. E., R. A. Wahl, D. Branscheid, K. Joseph, A. Tsuchiya, and H. D. Roher (1985). Indication for operation of patients with autonomously functioning thyroid tissues in endemic goiter area. World J. Surg. 9, 149-155.

Hamburger, L. T. (1980). Evolution of toxicity in solitary nontoxic autonomously functioning thyroid nodules. J. Clin. Endocrinol. Metab. 50, 1089-1093.

Hamburger, J. I. (1987). The autonomously functioning thyroid nodule: Goetsch' disease. Endocr. Rev. 8, 439-447.

Hosoya, T., I. Sato, Y. Hiyama, H. Yoshimura, H. Niimi and O. Tarutani (1985). An improved assay method for thyroid peroxidase applicable for a few milligrams of abnormal human thyroid tissues. J. Biochem. (Tokyo) 98, 637-647.

Ishida, T., H. Sato, H. Hosono, N. Abe, T. Kawai and M. Izuo (1983). Functioning thyroid nodules; Physiopathological comparison between adenomatous goiter and adenoma. Horumon to Rinshou (Hormones and Clinics) 31, 621-626 (in Japnese).

Ito. K. (1984). Functional aspect of thyroid tumors. Nippon Geka Gakkai Zasshi (J. Jpn. Surg. Soc) 85, 1019-1022 (in Japanese).

Lowry, O. H., N. J. Rosebrough, A. L. Farr and R. L. Randall (1951). Protein measurement with folin phenol reagent. J. Biol. Chem. 193, 265-275.

Miller, J. M. and J. I. Hamburger (1965). The thyroid acintigram I. The hot nodule. Radio$\log y$ 84, 66-73.

Nagasaka, A., H. Hidaka and Y. Ishizuki(1975). Studies on human iodide peroxidase: its activity in various thyroid disorders. Clin. Chim. Acta 62, 1-4.

Nakashima, T. and A. Taurog (1978). Improved assay procedures for thyroid peroxidase: application to normal and adenomatous human thyroid tissues. Clin. Chim. Acta 83, 129-140.

Ozaki, O., K. Ito, Y. Manabe and T. Mimura (1988). Adenomatous goiter with hyperthyroidism. Jpn. J. Surg. 18, 146-151.

Scriba, P. C., C. Beckers, H. Burgi E. Del Rey, M. Gembicki, A. K. Koutras, B. A. Lemberg, P. Langer, J. H. Lazarus, A. Querido, C. Thilly and R. Vigneti (1985). Goitre and iodine deficiency in Europe. Lancet 1, 1289-1293.

Takamatsu, J., T. Hosoya, N. Naito, H. Yoshimura, Y. Kohno, O. Tarutani, K. Kuma, S. Sakane, K. Takeda and T. Mozai (1988). Enhanced thyroid iodine metabolism in patients with triiodothyronine-predominant Graves' disease. J. Clin. Endocrinol. Metab. $66,147-152$.

Torizuka, K. (1978). Iodine metabolism and thyroid diseases in Japanese. Proceedings of Asia and Oceania Thyroid Association Workshops on Endemic Goitre and Thyroid Testing (Ed. by B. S. Heitzel, M. L. Wellby and R. Hosch1) pp. 11-12.

Valenta, L. J. (1976). Thyroid peroxidase, thyroglobulin, cAMP and DNA in human thyroid. J. Clin. Endocrinol. Metab. 43, 466469.

Yoshimura, H., K. Ito, O. Tarutani, and T. Hosoya (1988). Peroxidase activity and thyroglobulin iodination activity of thyroid peroxidase in autonomously functioning thyroid nodules. Acta Endocrinol. (Copenh) 118, 147153. 